skilled workers and technicians. The project was implemented as part of the teacher training and development program offered by Las Tunas University in partnership with Las Tunas Department of Basic Education to different TVET institutions. These limitations are:

- Teachers frequently present fragmented subject content that is decontextualized from real life situations.

- Teachers persistent use of traditional problems; this is not enough to promote the development of skills to approach novel situations and deal with real life problems.

- Occasionally, problems are solved and the field of application is not taken into consideration.

- During lessons, teachers do not draw attention to real life application of concepts. These limitations in approach of teachers negatively impact on students because:

- Students solve problems mechanically or without a deep understanding of theories.

-Students are unable to solve real life problems.

This situation shows contradictions between the demand for preparing a technically competent and skilled Cuban workforce and the preparation of TVET teachers.

Given the above, the following problem was identified: What would lead to improvements in the educational preparation of Vehicle Service Technicians who need to solve the diversity of professional problems they face in workshops?

Considering that most of Cuban vehicle and transport infrastructures are underdeveloped and have been used for more than 20 years this has had a significant impact on the environment (Cuesta Santos, et al., 2019). Vehicle Service Technicians were therefore taken as a priority to develop environmentally sound education projects.

\section{PROJECT BASED LEARNING}

This article looks at the problem outlined above through the lens of project-based learning (PBL) pedagogy. PBL engages students with learning and school through active exploration of real world problems and challenges. Students explore, make judgments, interpret, and synthesize information in meaningful ways (Harun, 2006). The authors provide an overview of how TVET teachers embraced some key issues regarding PBL pedagogy and an example of their efforts with PBL implementation based on the Cuban educational context.

To begin a literature review showed that the roots of PBL were in the progressive educational movement which promoted more student involvement and engagement (Peterson, 2012). It was recognized that William Heard Kilpatrick developed the "Project
Method" inspired by the philosophy of John Dewey (Chipman \& McDonald, 1980). Evidence also highlighted the concept of learning through projects that was developed in the $17^{\text {th }}$ and $18^{\text {th }}$ centuries (Knoll, 1997).

We then asked How is PBL defined? Research on this topic showed that PBL is defined in different ways. Some authors considered it as a pedagogy, while other authors considered it as a pedagogical approach, an active style of learning, a type of inquiry-based learning, or a method.

For example, Bell defined PBL as "a student-driven, teacher-facilitated approach to learning because students pursue knowledge by asking questions that have attracted their natural curiosity" (Bell, 2010). On the other hand, "PBL is considered to be a particular type of inquiry-based learning where the context of learning is provided through authentic questions and problems within real-world practices" (Al-Balushi \& Al-Aamri, 2014).

As stated by these two definitions, PBL is student-centered and it places students in the active role of problem solvers but it is seen as a learning approach based on the concept of inquiry-based learning.

For our context and project oriented purpose, the definition of PBL as a method was assumed.

"PBL is a teaching method in which students gain knowledge and skills by working for an extended period of time to investigate and respond to an authentic, engaging, and complex question, problem, or challenge" (Buck Institude of Education, 2018).

As stated by (Knoll, 1997) "The project is one of the standard teaching methods. It is generally considered a means by which students can (a) develop independence and responsibility, and (b) practice social and democratic modes of behavior".

Knoll definition reinforces the idea of PBL as a student-centered teaching method but it introduces other elements such as the development of attitudes and values.

PBL is student driven, (Bell, 2010) and that is why it usually begins with a driving question or real life problem which leads to the creation of an artifact (model, design, device, computer program, arts, etc.) by mean of completion a variety of tasks. The socialization aspects of the project are critical but enquiry processes involve written and oral ways of summarizing the procedure used to produce the product and present the outcomes. The following benefits of PBL were part of what we hoped to achieve:

- Provision of an integrated approach to understanding concepts and knowledge.

- Development of practice and research (evidence-based) skills.

- Facilitation of collaborative learning and team work.

- Facilitation of interdisciplinary work (connections across different subjects). 
- Provision of stronger and more relevant preparation for practice.

- Improvement in learner engagement in school.

- Strengthening of learner motivation and interest.

- Making learning experiences more relevant and meaningful.

- Allowing teachers to assign projects for students with a diverse variety of interests, motivations, intelligences, learning styles, abilities, career aspiration and personal backgrounds.

Thus we posed another question: What must a project have in order to be considered PBL?

These are some design principles of PBL (Thomas, 2000).

- Centrality of core curriculum elements consistent with PBL methodology.

- Driving Questions: PBL methods are focused on real life questions and problems which catch student attention and "drive" students to propose solutions considering the central concepts of PBL and the principles underpinning a discipline.

- Constructive Investigations: PBL involves students in a constructive investigation, in this way, students are familiarized with the scientific method and current scientist activities.

- Autonomy: PBL methods are student driven and the teacher plays the role of facilitator or mentor.

- Realism: PBL events are not simple learning activities to be covered during a lesson. The approach enables students to look at real world challenges.

To implement PBL as a project different phases need to be considered (Tellez Lazo, 2005):

First phase: Identification of the problem or driving question. The problem can never be imposed by the teacher. The students are free to choose the problem to be investigated but it must be in accordance with the core curriculum elements and the needs of the school and the company in which it will be implemented.

Second phase: Analysis of necessary human and materials resources. It is important to analyze the availability of material resources to complete the project as well as the class in terms of diversity (Intelligence, learning styles and economic, educational and cultural backgrounds).

Third Phase: Design of action plan - These actions are planned from theoretical and practical points of view. $\mathrm{PBL}$ is student driven and that is why the teacher serves as a facilitator guiding this phase. Students would be more committed with the project if they have an active role in deciding activities (Harun, 2006).

Fourth Phase: Execution of designed actions. This is the longest phase. Here, individual and group work take places. The students socialize to achieve the results in collaborative ways. As the objectives of the project are achieved, professional and research skills are developed.

Fifth Phase: Presentation of results. Students write about and pres- ent the results. This is important to develop language skills.

Sixth Phase: Project evaluation. A variety of assessment methods are used such as self-assessment, peer assessment and group assessment. Not only the results are assessed but also the whole process and development of skills, values and attitudes.

These phases can be summarized in the Project Based Cycle (see Figure 1).

\section{AUTOMOBLE MECHANICS EXAMPLE}

\section{Project overview}

Pollution is a serious problem. Scientists are now worried about its influences in changing the Earth's atmosphere because of carbon dioxide emissions from cars and industry. If we do not do something quickly, the Earth's ecosystem, including its weather, might be quite different in the next centuries. Every year the burning of fossil fuels and tropical forests releases over ten billion tons of carbon into the atmosphere (UN, 2018).

One needs to ask: Is life experience really better than it was a hundred years ago? It is certainly true that people live longer than they used to, travel faster than they could and own more things than they did. Humans have made great progress in industry, science, technology and medicine but we still have to tolerate noise and bad air which are critical challenges of modern life. Industry and modern life do not have to be enemies of beauty. Progress does not need to be aggressive. It does not have to destroy nature. We can have both beauty and progress if we really want this. We need clean rivers and open countryside just as much as a hundred years

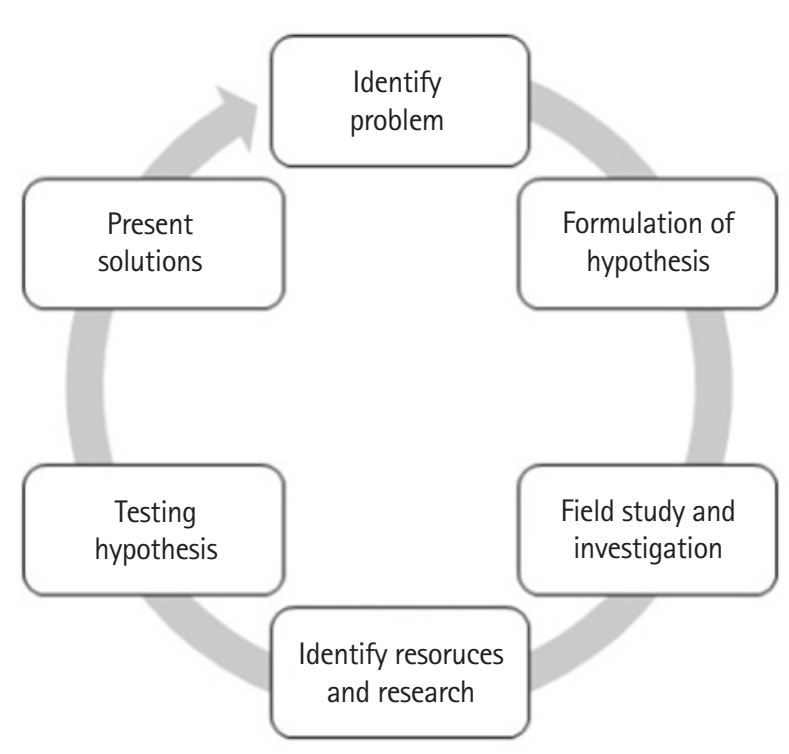

Figure 1. Project Based Learning Cycle 
ago. Perhaps, in some ways, we need them even more. Things like open land, clean water and good air are becoming unusual and infrequent all over the world. These environmental changes have brought the international community to adopt global, regional, national and local measures to prevent and control its impacts (Statistics and Information National Office, 2015).

For these reasons, the following project was proposed; it takes place at the service workshop of the Municipal Transportation Company in Jobabo Municipality, Las Tunas province, in the Republic of Cuba. This Government Company is responsible for the urban and rural public transportation within the municipality and its workshop serves as a classroom to carry out the practical lessons of "Manifiesto de Montecristi" Technical and Vocational School and the place where learners develop their volunteer community service.

The staff of this workshop did not accomplish the Environmental Security Standards concerning oils, greases and residual fuels disposal during maintenance and reparation of the motor vehicles and they do not have the grease traps that are established protocols. Lubricants and fuels were spilled and spread out all over the ground and mixed with water, polluting the soil, underground and runoff waters. Any grease that enters to grease trap or interceptor is called 'brown grease.' This grease needs to be disposed of appropriately. This recovered grease is often suitable for recycling in to bio-diesel and thus it can have some value.

\section{Driving Question/Problem}

The key question was "How do practitioners improve achievement of the Environmental Security Standards, implement sustainable measures concerning oils, greases and residual fuels disposal during maintenances and reparations of motor vehicles?"

The project outlined provided students interested in sustainable development with the foundational concepts for engagement with the future sequence of courses such as those available to automobile mechanics, mechanics, other practitioners eg those involved with pollution, conservation, recycling, maintenance of safety and security rules.

\section{Hypothesis}

The following hypothesis was proposed:

If sustainable measures concerning oils, greases and residual fuels disposal during maintenance and reparation of motor vehicles are used, the Environmental Security Standards in the workshop area and the community would be improved.

\section{General objective}

Upon completion of this project, students should be able to use critical thinking processes to develop a system for maintenance and reparation of motor vehicles that incorporates basic ecological principles and sustainable management practices which contribute to the development of values such as love for nature, friendship and responsibility; under supervision of senior teachers and technicians.

\section{Specific objectives}

To develop enquiry and processing skills that will enable students to assume roles that enable them to:

- Identify the key principles of sustainable development.

- Describe several different models of sustainable development.

- Apply the principles of sustainable development and environmental friendly measures during reparation and maintenance of motor vehicles to keep them in good running conditions.

- Observe the global, regional, national and local environmental regulations.

- Examine vehicles to ascertain the nature and location of defects either by running engine or driving vehicles on road to prevent environmental damages during its operation.

- Dismantle partially or completely defective unit or parts of vehicle such as engine, gear box, rear axle, front axle, steering assembly, radiator, etc. according to nature of repairs to be done, using hoist, jack, pullers, hand tools and other devices applying safety and environmental friendly measures.

- Lubricate joints, tighten loose parts, test performance of vehicle by driving on road and make necessary adjustments to attain desired safety and national environmental standards.

- Execute techniques concerning oils, greases and residual fuels disposal during maintenances and reparation of motor vehicles.

- Explain how to avoid soil and water pollution arising from use of fuels and lubricants.

- Investigate the different chemical components of fuels and lubricants that pollute the water.

- Develop an environmental awareness.

- Examine, quantitatively and qualitatively, the amount of fuels and lubricants spilled during maintenances.

- Calculate the economic losses due to the spilling of the lubricants during maintenance.

- Socialize in projects in a way that results in collaboration with other community members and workers.

\section{Group project requirements}

To organize the group work in a manner consistent with PBL, we proposed the following requirements:

- Groups of no more than five will be formed to complete the group portion of the project and ensure effective involvement. 
- Each member of the group will be given an area of responsibility.

- In case of a group with less than four members, each member may have more than one responsibility.

- In PBL it is important to place the student in the actual roles of the practitioners in the workplace. The roles were as follows:

Project leader: This member gets information to absent students, meets deadlines, fills absent members in, coordinates the efforts of the entire group, ensures that group members understand the functions/tasks, ensures that group members perform all assigned duties efficiently, supports other group members and readily provides additional assistance if needed.

Engineer: Main design ideas would come from this person; she/ he works with the leader in assigning the various functions/ tasks to group members. She/he adopts safety measures, personally, for the tools, job and environment.

Vehicle service technician: Provides maintenance and repair for motor vehicles observing the Environmental Security Standards established.

Manager: This member develops the budget, ensures group stays on budget, keeps financial records, builds components as assigned. Speaker/Communicator: This is the person who writes the report and presents the results of the project to other students and professionals in different scenarios, local and national events organized by the Department of Basic Education.

\section{Topics and concepts}

This project facilitates interdisciplinary work. Concepts from different subjects were integrated in situations/scenarios that were part of learning activities. For example:

Mechanics of Motor Vehicles: Internal combustion engine; Petrol Engine Basics; Gasoline Engine Basics; Exhaust emission test of petrol and diesel engine; Acoustic emission testing; Leak testing: Bubble emission testing, Air leak testing.

Environmental Factors: Soil pollution and conservation; Water pollution and conservation; Air pollution and conservation; Noise pollution.

Chemical Factors: Hydrocarbons; Fuels and combustion; Chemical components of fuels and lubricants; Exhaust emission gasses.

Mathematical Factors: Calculation of areas and volumes; Statistics. Physical Factors: Measurements and Measuring instruments; Work, energy and power; Hydrodynamic; Thermodynamics; Combustion engines.

Biological Factors: Ecosystems; Conservation.

Economic Factors: Cost; Economic losses.

\section{Materials and Resources}

Maintenances Observation Guide; Tools; Lubricants; Automotive Vehicles; Automobile parts; Manual of Mechanics of Automotive Vehicles; Rules of Usage of Fuels and Lubricants; Real life objects; Pictures and videos; Computers and stationery.

\section{Time Line}

The project was completed in four months, over the Christmas term from September to December. The first and second weeks were dedicated to diagnosing the relevant issues around environmental and working conditions within the workshop. During the third and fourth weeks a literature review on sustainable development practices was made. The second and third months the learners provide maintenance and repair motor vehicles and executed environmental friendly techniques concerning oils, greases and residual fuels disposal during maintenances and reparations. The last month learners evaluated the results. The presentation of results to other students was held at the end of the fourth month but the presentation of results to other professionals in different scenarios, local and national events organized by the Department of Basic Education was held after complexion of the project according to the academic year calendar.

\section{RESULTS}

The authors reflected on the benefits and challenges of project implementation.

\section{Benefits}

Upon completion of the project the following benefits can be summarized.

The project using Work-integrated learning consistent with PBL principles:

- Implemented sustainable development and environmental friendly techniques concerning oils, greases and residual fuels disposal during maintenances and reparations of motor vehicles which contributed to conserve the soil and water not only in the workshop area but the community as well.

- Promoted an environmental and production awareness at a School and Community level.

- Provided students with an integrated understanding of the concepts and knowledge on sustainable development.

- Developed practical and research skills, views and attitudes within the student group.

- Facilitated interdisciplinary work (connections across different subjects).

- Improved student motivation. 
- Made learning experiences more relevant and meaningful.

- Facilitated student use of processes of Practice and Inquiry-Based Learning and PBL.

\section{Challenges}

As every human activity, the project implementation was not perfect; some challenges arose:

- Some Vehicle Service Technicians underestimated learners' preparation and motivation and refused to share experiences with them.

- The students faced some concerns since they have to learn outside of school (field and home) with adults who are not trained educators such as Vehicle Service Technicians and Workshop Skill Workers.

\section{Project valuation}

This involved a range of appraisals of approaches to assessment and evaluation of the implementation of the project.

\section{General rubric for project written reports}

A rubric with seven indicators consistent with PBL to assess different levels of performance was proposed to evaluate the project written report (see Table 1 ).

\section{General rubric for oral presentations of projects}

A rubric with seven indicators and different levels of student performance was proposed to evaluate oral presentations of projects (see Table 2).

Table 1. General Rubric for Project written reports

\begin{tabular}{|c|c|c|c|c|c|}
\hline \multirow{2}{*}{ Indicators } & \multicolumn{5}{|c|}{ Levels of performance } \\
\hline & Exemplary & Proficient & Satisfactory & Below standard & Unsatisfactory \\
\hline Information sources & $\begin{array}{l}\text { Used a variety of rele- } \\
\text { vant sources (three or } \\
\text { more different types } \\
\text { and several of each } \\
\text { type of source). Cited } \\
\text { all sources. }\end{array}$ & $\begin{array}{l}\text { Used many sources of } \\
\text { two types. Cited all } \\
\text { sources. }\end{array}$ & $\begin{array}{l}\text { Used many sources of } \\
\text { one type (e.g. text- } \\
\text { books, Internet, jour- } \\
\text { nals, magazines, } \\
\text { questionnaire. Sources } \\
\text { were referenced. }\end{array}$ & $\begin{array}{l}\text { Two or three sources } \\
\text { were used. }\end{array}$ & $\begin{array}{l}\text { One source used and } \\
\text { referenced. }\end{array}$ \\
\hline $\begin{array}{l}\text { Sources had data to } \\
\text { support claims. }\end{array}$ & $\begin{array}{l}\text { All sources (but one) } \\
\text { had data to support } \\
\text { claims. }\end{array}$ & $\begin{array}{l}\text { Most sources had data } \\
\text { to support claims. }\end{array}$ & $\begin{array}{l}\text { Some sources had data } \\
\text { to support claims. }\end{array}$ & $\begin{array}{l}\text { One source had data to } \\
\text { support claims. }\end{array}$ & $\begin{array}{l}\text { No source had data to } \\
\text { support claims. }\end{array}$ \\
\hline $\begin{array}{l}\text { Extracted relevant in- } \\
\text { formation. }\end{array}$ & $\begin{array}{l}\text { All information extract- } \\
\text { ed was relevant to the } \\
\text { topic. }\end{array}$ & $\begin{array}{l}\text { All information extract- } \\
\text { ed was relevant to the } \\
\text { topic. However, no in- } \\
\text { formation was given } \\
\text { for one aspect. }\end{array}$ & $\begin{array}{l}\text { Some relevant and } \\
\text { some irrelevant infor- } \\
\text { mation was extracted. }\end{array}$ & $\begin{array}{l}\text { Little relevant informa- } \\
\text { tion was extracted. }\end{array}$ & $\begin{array}{l}\text { Little information was } \\
\text { extracted; it was } \\
\text { mainly irrelevant. }\end{array}$ \\
\hline $\begin{array}{l}\text { Paraphrased informa- } \\
\text { tion. }\end{array}$ & $\begin{array}{l}\text { All information extract- } \\
\text { ed was paraphrased } \\
\text { and well written. }\end{array}$ & $\begin{array}{l}\text { Most information was } \\
\text { paraphrased and well } \\
\text { written. }\end{array}$ & $\begin{array}{l}\text { Some information was } \\
\text { paraphrased. Howev- } \\
\text { er, copied portions } \\
\text { were not indicated. }\end{array}$ & $\begin{array}{l}\text { Most information was } \\
\text { copied from sources. }\end{array}$ & $\begin{array}{l}\text { All information was } \\
\text { copied from sources. }\end{array}$ \\
\hline Organized information. & $\begin{array}{l}\text { Information was very } \\
\text { clearly and sequen- } \\
\text { tially organized. The } \\
\text { position was logically } \\
\text { stated with support- } \\
\text { ing data. Alternative } \\
\text { points of view were } \\
\text { included. }\end{array}$ & $\begin{array}{l}\text { Information is clearly } \\
\text { and sequentially or- } \\
\text { ganized. Logically } \\
\text { stated position with } \\
\text { supporting data. }\end{array}$ & $\begin{array}{l}\text { Information was clearly } \\
\text { and sequentially or- } \\
\text { ganized. }\end{array}$ & $\begin{array}{l}\text { Information was se- } \\
\text { quentially organized. }\end{array}$ & $\begin{array}{l}\text { Information was writ- } \\
\text { ten haphazardly. }\end{array}$ \\
\hline Synthesized & $\begin{array}{l}\text { Project clearly and ar- } \\
\text { ticulately showed: } \\
\text { problem, hypothesis, } \\
\text { method of research, } \\
\text { literature reviewed, } \\
\text { findings, analysis of } \\
\text { findings, position. }\end{array}$ & $\begin{array}{l}\text { Project showed: prob- } \\
\text { lem, hypothesis, } \\
\text { method of research, } \\
\text { literature reviewed, } \\
\text { findings, analysis of } \\
\text { findings, position. }\end{array}$ & $\begin{array}{l}\text { Project showed prob- } \\
\text { lem, hypothesis, } \\
\text { method of research, } \\
\text { literature reviewed, } \\
\text { findings, analysis of } \\
\text { findings, position (one } \\
\text { missing). }\end{array}$ & $\begin{array}{l}\text { Project showed prob- } \\
\text { lem, hypothesis, } \\
\text { method of research, } \\
\text { findings. }\end{array}$ & $\begin{array}{l}\text { Notes shown on aspects } \\
\text { of the project. }\end{array}$ \\
\hline Language & $\begin{array}{l}\text { Write clearly and dis- } \\
\text { tinctly throughout the } \\
\text { report, does not have } \\
\text { writing errors. }\end{array}$ & $\begin{array}{l}\text { Write clearly and dis- } \\
\text { tinctly throughout the } \\
\text { report, have no more } \\
\text { than two writing er- } \\
\text { rors. }\end{array}$ & $\begin{array}{l}\text { Write clearly and dis- } \\
\text { tinctly for most of the } \\
\text { report, makes no more } \\
\text { than two grammatical } \\
\text { and writing errors. }\end{array}$ & $\begin{array}{l}\text { Misuse key vocabulary, } \\
\text { have more than two } \\
\text { grammatical and } \\
\text { writing errors. }\end{array}$ & $\begin{array}{l}\text { Misuse key vocabulary, } \\
\text { have more than ten } \\
\text { grammatical and } \\
\text { writing errors. }\end{array}$ \\
\hline Grade & A $86-100$ & B $71-85$ & C $56-70$ & D $41-55$ & F 40 and lower \\
\hline
\end{tabular}


Table 2. General Rubric for oral presentations of projects

\begin{tabular}{|c|c|c|c|c|c|}
\hline \multirow{2}{*}{ Indicators } & \multicolumn{5}{|c|}{ Levels of performance } \\
\hline & Exemplary & Proficient & Satisfactory & Below standard & Unsatisfactory \\
\hline Preparedness & Completely prepared. & $\begin{array}{l}\text { Seemed well prepared } \\
\text { but could have spent } \\
\text { more time rehearsing. }\end{array}$ & $\begin{array}{l}\text { Somewhat prepared, } \\
\text { but seems not to have } \\
\text { rehearsed. }\end{array}$ & $\begin{array}{l}\text { Did not seem prepared } \\
\text { to present. }\end{array}$ & $\begin{array}{l}\text { Appeared to have made } \\
\text { no effort to prepare. }\end{array}$ \\
\hline Time/length & $\begin{array}{l}\text { Duration was for the } \\
\text { required time. }\end{array}$ & $\begin{array}{l}\text { Duration was longer or } \\
\text { shorter than the time } \\
\text { allotted by } 0-20 \% \\
\text { of duration. }\end{array}$ & $\begin{array}{l}\text { Duration was longer or } \\
\text { shorter than the time } \\
\text { allotted by } 21-30 \% \\
\text { of duration. }\end{array}$ & $\begin{array}{l}\text { Duration was longer or } \\
\text { shorter than the time } \\
\text { allotted by } 31-40 \% \\
\text { of duration. }\end{array}$ & $\begin{array}{l}\text { Duration was longer or } \\
\text { shorter than the time } \\
\text { allotted by } 41-67 \% \\
\text { of duration. }\end{array}$ \\
\hline Language & $\begin{array}{l}\text { Speaks clearly and dis- } \\
\text { tinctly throughout the } \\
\text { presentation, does not } \\
\text { mispronounce words. }\end{array}$ & $\begin{array}{l}\text { Speaks clearly and dis- } \\
\text { tinctly throughout the } \\
\text { presentation, mispro- } \\
\text { nounced one and two } \\
\text { words. }\end{array}$ & $\begin{array}{l}\text { Speaks clearly and dis- } \\
\text { tinctly for most of the } \\
\text { presentation, mispro- } \\
\text { nounces key vocabu- } \\
\text { lary or makes one or } \\
\text { two grammatical er- } \\
\text { rors. }\end{array}$ & $\begin{array}{l}\text { Mumbles at one or two } \\
\text { points, more than two } \\
\text { grammatical errors. }\end{array}$ & $\begin{array}{l}\text { Mumbles most of the } \\
\text { presentation, mispro- } \\
\text { nunciation and gram- } \\
\text { matical errors. }\end{array}$ \\
\hline $\begin{array}{l}\text { Effectiveness in making } \\
\text { a point. }\end{array}$ & $\begin{array}{l}\text { Song etc. was very ef- } \\
\text { fective in marketing } \\
\text { its message. }\end{array}$ & $\begin{array}{l}\text { Song etc. made a point } \\
\text { strongly. }\end{array}$ & $\begin{array}{l}\text { Song etc. made a point } \\
\text { related to the topic. }\end{array}$ & $\begin{array}{l}\text { Information in the song } \\
\text { etc. was disjointed. }\end{array}$ & $\begin{array}{l}\text { Lyrics did not portray a } \\
\text { theme. }\end{array}$ \\
\hline Creativity & $\begin{array}{l}\text { A very high level of cre- } \\
\text { ativity shown. }\end{array}$ & $\begin{array}{l}\text { A good standard of cre- } \\
\text { ativity shown. }\end{array}$ & Some creativity shown. & Creativity shown. & $\begin{array}{l}\text { Little or no evidence of } \\
\text { creativity is shown. }\end{array}$ \\
\hline
\end{tabular}

\section{Project evaluation questionnaire}

A questionnaire was developed for feedback from teachers (see Table 3 and 4).

\section{CONCLUSIONS}

This project was an example of Work-integrated learning that provides insights on what can be done in terms of contributing to sustainable development at a school and community level. It involved TVET teachers in engagement with some key elements of PBL pedagogy as an example of Automobile Mechanics Project based on the Cuban educational context, in which one of the atmospheric and air pollution source is the transport infrastructure running with obsolete motor vehicles. This approach ensured students acquired not only subject content knowledge but also skills and attitudes to meet complex demands; the project was drawing on and mobilizing resources to solve professional problems in a particular context with an interdisciplinary perspective. The exam- ple provided increased students motivation, participation and engagement and at the same time it contributed to outcomes consistent with deeper and more meaningful learning than otherwise might have occurred when students are exposed to more passive experiences.

\section{ACKNOWLEDGEMENTS}

Our deepest appreciation to all those who provided us the possibility to complete this paper. A special gratitude we give to the associate editor of the Journal of Problem-Based Learning, Dr. Meeyoung Park, whose contribution in stimulating suggestions and encouragement, helped us to improve this article, especially in writing it. Furthermore, we would also like to acknowledge with much appreciation the crucial role of the Journal of Problem-Based Learning, which gave us the opportunity to publish and socialize this experience. 
Table 3. Question 1. Below are a series of statements. Please respond by circling the number you feel most reflects your opinion

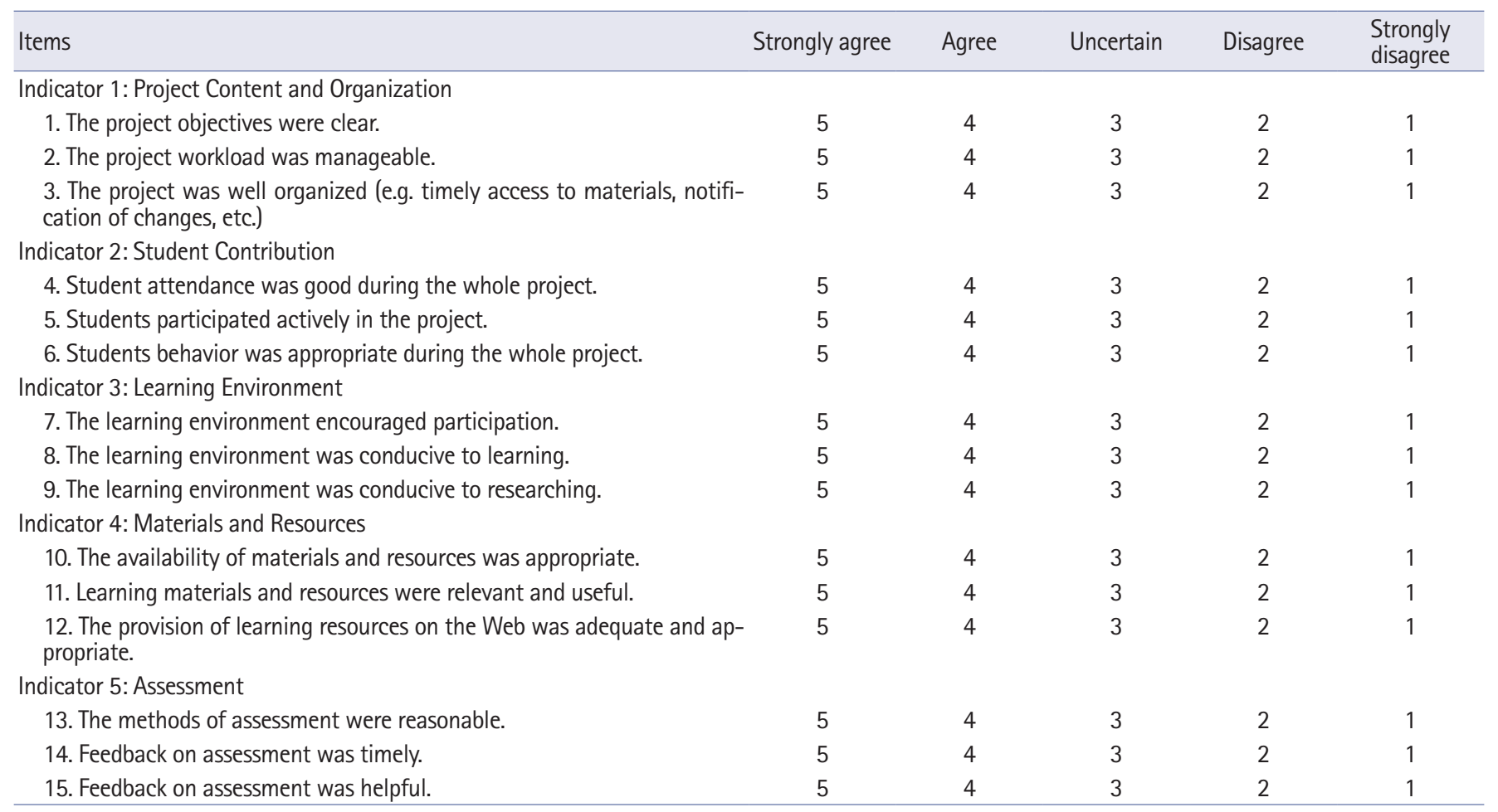

This questionnaire is a survey evaluating projects as part of the institutional self-evaluation of "Manifiesto de Montecristi" Technical and Vocational Education School. The survey provides you an opportunity to evaluate the projects you were involved in the previous academic year. You are kindly requested to give your opinion trough filling in the questionnaire provided.

Table 4. Question \#2: Indicate the level of achievement during the project

\begin{tabular}{|c|c|c|c|c|c|}
\hline Items & Excellent & Very good & Good & Fair & Poor \\
\hline \multicolumn{6}{|l|}{ Indicator 6: Knowledge } \\
\hline 16. Mathematics, Science, Humanities and professional disciplines. & 5 & 4 & 3 & 2 & 1 \\
\hline 18. Collecting and analyzing appropriate data. & 5 & 4 & 3 & 2 & 1 \\
\hline 19. Ability to link theory to practice. & 5 & 4 & 3 & 2 & 1 \\
\hline 20. Computer knowledge. & 5 & 4 & 3 & 2 & 1 \\
\hline 22. Report writing. & 5 & 4 & 3 & 2 & 1 \\
\hline 23. Presentation skills. & 5 & 4 & 3 & 2 & 1 \\
\hline \multicolumn{6}{|l|}{ Indicator 8: Interpersonal Skills } \\
\hline 24. Ability to work in teams. & 5 & 4 & 3 & 2 & 1 \\
\hline 25. Leadership. & 5 & 4 & 3 & 2 & 1 \\
\hline 29. Appreciation of ethical values. & 5 & 4 & 3 & 2 & 1 \\
\hline \multicolumn{6}{|l|}{ Indicator 9: Work skills } \\
\hline 30. Time management skills. & 5 & 4 & 3 & 2 & 1 \\
\hline 31. Judgment. & 5 & 4 & 3 & 2 & 1 \\
\hline 32. Discipline & 5 & 4 & 3 & 2 & 1 \\
\hline
\end{tabular}

Thank you for the time to answer all the questions. 


\section{REFERENCES}

Al-Balushi, S. M., \& Al-Aamri, S. S. (2014). The effect of environmental science projects on students' environmental knowledge and science attitudes. International Research in Geographical and Environmental Science, 23(3), 213-227.

Bell, S. (2010). In: Project-Based Learning for the 21st Century: Skills for teh future. In: Routledge The Clearing House, 39-46.

Buck Institude of Education. (2018). BIE. Retrieved from http:// www.bie.org/about/what_pbl

Chipman, D., \& McDonald, C. (1980). The Historical Contributions of William Heard Kilpatrick. Journal of Thought, 15(1), $71-83$.

Cuesta Santos, O., González González, M. L., Sánchez Navarro, P., Collazo, A., Wallo, A., \& Guevara Velazco, A. (2019). Air quality computation in outdoor and indoor environment in humid tropic (Cuba). La Habana Retrieved from https:// pdfs.semanticscholar.org/a0a4/ad242e3f3995cfbf54f56456f3bf5abbdfaf.pdf

Harun, Y. (2006). Project-Based Learning handbook Educating the Millennial Learner. Kuala Lumpur: Educational Technology Division Ministry of Education
Knoll, M. (1997). The project method: Its vocational education origin and international development. Journal of Industrial Teacher Education, 34(3), 59-80.

Peterson, B. W. (2012). Uncovering the Progressive Past: The Origins of Project Based Learning. unBoxed. A Journal of Adult Learning in Schools 2012(8)Retrieved from https://gse. hightechhigh.org/unboxed/issue8/ uncovering_the_progressive_past/

Statistics and Information National Office. (2015). Cuban Statistical Yearbook. La Habana: ONEI. Retrieved from http:// www. onei.cu

Tellez Lazo, L. (2005). Didactic model of Project as a way of organizing the professional practice of electricity technicians. Unpublished master's thesis. Pedagogical University José de la Luz y Caballero, Holguin.

Thomas, J. W. (2000). Buck Institute for Education. Retrieved from http://www.bie.org/images/uploads/general/9d06758fd346969cb63653d00dca55c0.pdf

UN. (2018). Emissions Gap Report 2018. UNEP DTU Partnership. Retrieved from https://www.ipcc.ch/site/assets/uploads/2018/12/UNEP-1.pdf 